\title{
THE MANIFESTATION OF SOCIAL REPRESENTATION THEORY AND SOCIAL CAPITAL IN A GENTRIFIED NEIGHBOURHOOD IN A POST-SOCIALIST COUNTRY, ESTONIA
}

\author{
Nele Nutt ${ }^{1}$, Zenia Kotval ${ }^{1,2}$, Kadri Mets ${ }^{1}$, Sirle Salmistu ${ }^{1}$ \\ ${ }^{1}$ Tartu College at the Tallinn University of Technology and \\ ${ }^{2}$ Michigan State University
}

\begin{abstract}
In the constantly changing network of social and cultural processes in contemporarymodern societies, a cultural internalization is occurring, during which the dictated rules and regulations of society become a part of human character. This article discusses how people who live within a community identify themselves and construct the social character of that area in the context of gentrification. Two theories are discussed to explain this phenomenon: social representation theory and social capital theory. Gentrification of the neighbourhood as the simultaneous process has laid out the scene and has created the context for this study. A community can be identified by the neighbourhood and the resulting intertwined relationships. The community of Supilinn neighbourhood in Tartu city, Estonia has been explored.
\end{abstract}

Keywords: social capital, social representation theory, gentrification, community activity, neighbourhood, post-Soviet

DOI: https//doi.org/10.3176/tr.2021.2.01

Received 2 March 2020, accepted 2 March 2021, printed and available online 10 June 2021

\section{Introduction}

Sociologists and other researchers and professionals alike have stressed the importance of a sense of place for decades. As discussed by Arefi (1999), the sense of place examines people's ties and attachment to their places. Characterizing a good place from a planning perspective, Friedmann (2010) points out place attachment as 
an invisible and subjective attribute as one of the four key features. Place attachment provides an insight how people feel about their community and how they engage with other people and their surroundings (Amsden et al. 2011). Furthermore, place attachment and belonging to a community are essential criteria of wellbeing for many people (Corcoran 2002). However, place identity often becomes unrecognizable during the gentrification process. The best way for building social capital and preserving community coherence is by community participation in the decisionmaking processes that concern the future of the neighbourhood (Crawford et al. 2008). This article discusses how people who live within a gentrifying community identify themselves and construct the social character of that area. Place attachment and other social dimensions are closely linked to the place-making process that local people use to form, i.e. create and re-create the place. Thus, the concept of social capital and social representation theory have been analysed on the example of Supilinn neighbourhood in Tartu city, Estonia. Social representation theory and social capital may appear in various contexts and situations. Gentrification of the neighbourhood as the simultaneous urban process has laid out the scene and has created the conceptual framework for this study.

Supilinn has been chosen as the object of this case study for the following reasons:

1. The area is in the process of gentrification. This makes it possible to study how gentrification is connected to other social phenomena, such as the social representation theory and social capital.

2. There is an active local neighbourhood association, which promotes the values of civil society. This provides an opportunity to observe the construction of the phenomena according to social representation theory.

3. The historical substance enables to study the connections between physical and social environment from the perspectives of social capital and construction of social representation.

The purpose of this article is to explore the manifestation of the social representation theory and social capital in Supilinn district in Tartu, Estonia. Hence, the research questions pose how do the residents of the area construct the phenomenon of social representation, and how do the residents use this constructed phenomenon as social capital in a gentrifying area?

To date, Supilinn neighbourhood has been studied in terms of gentrification, but there is a gap in exploring the relationship between gentrification and other concepts of social phenomena, including connections to social representation theory and social capital. Previous research regarding Supilinn includes the exploration of the values of architecture and historical milieu in Supilinn neighbourhood by Nutt (2003), Hiob and colleagues (2012); the course and dynamics of gentrification in the region by Nutt (2012) as well as the issues and specifics of gentrification process within the development of post-socialist countries (Nutt et al. 2012, 2013, 2016). Hiob and Nutt (2016) have studied the gentrification in the context of spatial planning, and the liveability and convenience within the gentrification area have been explored by Nutt (2017). 
This article attempts to contribute in the body of knowledge related to studies understanding gentrification processes and implications in Supilinn neighbourhood simultaneously to other social processes. The results will inform researchers, planning professionals and decision-makers of complex issues of community planning and social processes. Also, it will demonstrate how social representation theory and social capital are linked to a gentrified community. In other words, this article illustrates how gentrification can contribute to the production of social capital.

\section{Theoretical framework}

\subsection{Overview of social representation theory}

According to Wagner (1998), social representation theory deals with the matter of how members of the population give sense to the most diverse phenomena. The social aspect, herein, stands for the relationship between the individual and the object, event or phenomenon that belongs in the world of their social group. The relationship between the person and the world should be understood through the eyes of the group because a socially relevant world does not exist independently without the people in it and people in the group only calibrate their world view through the discourse. Necessary tools for establishing our beliefs and reliable sources for the knowledge become apparent through the discourse. The construction is also an important part of social representation if we want to understand the social aspect of constructing an object. An object is any material, imaginary or symbolic entity that people name and designate characteristics or values to and of which can be discussed. Object functions are always clear to people as the object always exists in a similar way to a particular group. Social representation is the explanation of the object. A constructive event stands for a situation in which something is given a name. Properties are attributed to something, and it becomes meaningful in the social world.

Social representation is a phenomenon that brings people together, it is recognized in the media and it has a lot of metaphorical stories (Wagner 1998). Moscovici (1984) proceeded to develop the theory of social representation relying on the idea that people's everyday lives are guided by imaginations of consensual nature that are developed in the communication process. Based on Wagner (1998), these imaginations replay (re-present) socially significant aspects of the outside world for the members of the group. Representation is the relationship between three elements: subjects aka carriers of representation; object that is represented, specific phenomenon or abstract idea; and a project aka pragmatic context, according to social groups, in which the representation is meaningful or intelligible. These three elements form an integrated system in which the latter acts as a mediator for the other two elements. In order to understand how object, project, and subject are represented or in which manner the object and subject are related to the project, it is most important to focus on studying the structure of the representation. A communicative act that creates representations consists of at least two subjects, and of an object in which they are mutually interested. It is important to note that the meanings are 
never individual or private, but always refer to the existence of another, real or imaginary. Although the form, function and content are individually attributed to the meaning, they are inevitably influencing this process through past social experiences (Wagner 1998). Context connects two subjects through common interests, goals, and activities (Bauer and Gaskell 1999). All the members of the group have a certain mutual part of the whole, but the whole can only be understood in the context of the collective. Representation is concurrently an individual and collective action for cultivating knowledge - improvement, circulation and adoption of the representation are responsible for the preservation and alteration of the knowledge. Representations facilitate the exchange of information inside the group as well as the achievement of individual and collective goals (Moscovici 1984).

An important part of imagination is the influence of the society. However, new structures will not prove to be effective if they do not find support for innovative thinking, which primarily consists of democratic civil culture, business ethics and interpersonal trust (Sztompka 1996). Hand in hand with major social changes, the way people think changes. Social phenomena are continuously re-evaluated. During rapid social changes, people are exposed to novel social phenomena (Rämmer 1998). Identifying with the region is mainly based on the constructed regional identity, which is formed out of the beliefs, preferences, feelings, values, etc. associated with the corresponding region (Proshansky 1978). It is a process that is constantly evolving and changing over time (Proshansky et al. 1983). Excessive fondness for the region can have negative, regressive characteristics. For example, collisions between different ideals and visions in which one main agenda to focus on cannot be found (Manzo 2003). This is emphasized when a wide range of interest groups, whose visions do not necessarily coincide, operate in public space (Ait 2015). The longer the people have been living in the relevant area (Taylor 1996) and the more advanced the organization is (Brown et al. 2003), the greater is the sense of place. Thus, identifying with the region or neighbourhood affects a person's behaviour as well as the neighbourhood in a broader sense.

\subsection{Overview of social capital theory}

Although a community is deeply connected to a specific place, social dimension is primarily important to its emergence and functioning. The main yardstick for community life is social capital.

Introduced in 1916 by Hanifan (1920) and defined almost 60 years later by Bourdieu (1977), the concept of social capital is the sum of actual and potential resources derived from a mutually recognised permanent network of acquaintances. Relationships between acquaintances exist in the form of material and/or symbolic exchanges. In order to possess social capital and access the collective capital one must participate in the group or network. This (incidentally) requires initial capital. Social capital also needs constant reproduction in order to survive. Each group is unique and has its own institutionalized forms for delegating social capital. Transferring the capital enables it to become concentrated, which is indispensable for the existence of the group (Käärik 2013). The theory of social capital makes it possible to analyse 
both contacts, public and personal, which are bilaterally beneficial. Strong social networks make it possible to reduce the crime in the area or even make a career. For example, local people are acquainted with their neighbours, thus strangers in the neighbourhood will not go unnoticed, which means the neighbourhood watch works efficiently. Also, the experience of organising specific community events (e.g. community festivals held by the neighbourhood association) can be added to one's resume, which in turn can lead to new contacts and career opportunities.

The definition of social capital became widely known in the beginning of the 1990s through the works of James S. Coleman and Robert D. Putnam. According to Coleman (1990), social capital, which is one aspect of a social structure, makes it possible to reach one's goals, which otherwise would not be possible, and at the same time by paying attention to the creation of human capital and educational outputs (Narayan and Cassidy 2001).

Theories dealing with social capital stress the importance of social connections and shared values in order to achieve social welfare and economic efficiency. According to Putnam (2000), social capital represents human ties - social networks and the mutual norms, which are derived from them. This can be understood as a structural and as a cultural phenomenon. Putnam, who has thoroughly researched the social capital of the American society, notes that civil society is interlaced with horizontal networks and associated with norms and values. These norms and values have far-reaching social consequences for both the people living in that society and for the society itself, by creating individual and collective benefits. The voluntary associations that Putnam studied have a particularly important role in this process. The active involvement of local people in organizations provides opportunities for them to make direct contacts with each other, helps the community achieve its goals, and encourages the acquisition of a broad range of skills, including interpersonal trust. In the book Bowling Alone Putnam (2000) argues that social capital has significant political consequences that impact democratic civil rights and the functioning of the government. His theory can be seen as a two-step model. In the first step, civil society directly supports social capital (social networks and cultural norms that emerge from civil society). Then the social capital contributes to people's participation in politics and to good governance practices (Norris and Inglehart 2004). In Putnam's opinion the possibility for social capital to emerge in vertically and horizontally built organizations is different because the horizontal structure favours the development of social trust and collective action. Horizontal organisations are created by people's own initiative, such as local neighbourhood associations that are characteristic to the civil society. Vertical organisations, however, are built as a hierarchy that everyone in the organisation has to follow. The idea behind the reasons of why these organizations withstand is not based on interpersonal relations and on the compatibility between people but on shared symbols and ideologies. American literature has emphasized the role of religious institutions in the formation of social capital. In particular, the mainstream Protestant churches in local communities have a vital role in bringing together different groups of people. This is also confirmed by Norris and Inglehart (2004), based on the results of their study. 


\section{Method and material}

The research combined rigorous quantitative and qualitative research methods, such as ethnographic method, a survey, and an interview. This research was conducted from 2010 to 2017.

Participant observation was used as the scientific ethnographic research method, which creates an opportunity for the theorist and the fieldworker to be the same person. Malinowski thought that this was important from the research point of view. Also, Radcliffe-Brown stressed that it was important to observe all the elements in the system within their context and analyse them according to the existing system (Haworth 1958). This research was guided by these principles. Fieldworks were conducted, photos were taken and notes on communication, events, attitudes, relationships, collaboration, initiatives etc. were recorded continuously.

In 2011 a structured mail survey was carried out. The questionnaire included factual questions, knowledge-related questions, closed Likert-scale opinions and open-ended questions. The survey was sent to all postal addresses in Supilinn district. There were 286 survey respondents, which comprised $16 \%$ of the population. The respondents were between 16 to 85 years old while most of the respondents were 25-45 years old (81\%). 59\% of the respondents were women and $41 \%$ were men. Slightly more than half of the respondents $(51 \%)$ were from the households with children. People with high academic degree comprised $64 \%$ of the respondents, which is an unproportionally high rate. The employment positions of respondents: $25 \%$ were specialists and office workers; $14 \%$ were managers, directors and top specialist; $14 \%$ were academics, i.e. researchers and professors/lecturers; and 13\% were creative professionals. Workers and service providers were 30 people $(11 \%)$, $9 \%$ were university students and only $7 \%$ were retired people. The majority of the respondents said that their economic situation was good $(34 \%)$ or average $(52 \%)$. The rate of the members of Supilinn association was relatively low (33 respondents, $12 \%), 87$ respondents said that they would like to become a member of the association $(31 \%)$. Still, there were 68 respondents who appeared in the association's mailing list (24\%) (Supilinna Selts 2011).

Interviews (30- to 60-minutes long) with open coding were conducted in 2011 with 11 key people, who were either active residents of Supilinn and people connected to the area (i.e. prominent opinion leaders who were not necessarily living in the area but were very familiar with the area, for instance a locally well-known writer, arthistorian or property developer).

The topics dealt within the course of the interviews included: my Supilinn, residents of Supilinn, values, characteristics, problems, the future and development trends. Qualitative content analysis and inductive approach were used for interview analysis, which enabled to understand the systems of participants' world interpretations and meanings (Ezzy 2002, Flick 2011). 


\section{Case study of Supilinn neighbourhood - understanding the gentrification process in the district}

\subsection{Occurrence of gentrification in Estonia as a post-socialist country}

Transformation from a centrally planned communist system to a market economy and liberal democracy after 1990 is characteristic to countries of Central and Eastern Europe. As discussed by Kubeš and Kovács (2020), rapid change in social and power relations has influenced the spatial patterns of cities - intensification of innercity neighbourhoods, change of population in various areas, and gentrification and urban renewal projects are the major changes. Kubeš and Kovács (2020: 2603) point out that specifics of post-socialist gentrification involve the long-lasting neglect of inner cities under socialism, the post-socialist way of restitution and privatisation of housing, the limited amount of capital both in the hand of potential gentrifiers and domestic property developers.

In Estonia, similarly to other socialist countries, the land and properties were owned by the state prior the collapse of the soviet regime and thus, the property market, which is essential to kick-start the gentrification process is completely absent. After the collapse of socialism and the establishment of independence, ownership reforms were carried out, and as a result, properties gained value and became the objects of sale. In Estonia, the property market started to develop after the Republic of Estonia regained independence in August 1991, and the land was returned to their legal owners. Thus, the gentrification process in Estonia has specific differences compared to the processes occurring in the Western countries (Nutt 2019). These historical reasons make gentrification evident as a contemporary social phenomenon (Kubeš and Kovács 2020, Nutt 2019).

\subsection{Notion of gentrification within this study, in Supilinn}

In general, gentrification is a phenomenon, which transforms the unpopular and poor/low-income city districts into a popular and wealthy areas. Since the 1960s, researchers have explored this process and sociologist Ruth Glass started using the term 'gentrification' (Atkinson 2004, Brouillette 2009, Grifith 1996). According to Grass, gentrification marks the process of middle-class people moving into slums or a poor neighbourhood, which changes the character of the place in a short period of time. Wealthy middle class clean and raise the quality of the area, and refurbish the dwellings. As a result, the image of the neighbourhood improves and property values increase as well, which are considered as positive effects of gentrification (Atkinson 2004). On the contrary, negative impacts of gentrification include crowding out poorer residents (Anderson et al. 2005, Atkinson 2000), and the displacement may end up with homelessness of former residents (Atkinson 2000, 2004).

Research on gentrification states that preconditions for starting the gentrification process should be met, which include the location of the area in the vicinity of city centre or downtown, and the existence of low-cost and degraded properties, which can be easily increased with small investments (Atkinson 2004). 
Theory of gentrification also points out that the process is occurring in several stages or so-called waves, whereas the first wave is initiated by the 'pioneers' who move in to the unpopular neighbourhood, the second wave is guided by the professionals with steady income, and the third wave is dominated by the wealthy middle class who prefer to live in the popular area. However, the dynamics of gentrification and the occurrence of gentrification waves in Supilinn neighbourhood is different. First, gentrification started after the changes in land ownership were established (i.e. after 1991), which is typical of the post-socialist countries, but the first wave initiators or pioneers - creative people - were already there. Almost ten years later, the second wave of gentrification could be identified, which culminated in the formation of the neighbourhood organisation in 2002. The arrival of the third wave gentrification was evident in 2017 when conflicts of values among residents were aroused (Nutt 2019).

\subsection{Supilinn neighbourhood}

The case study focuses on a historic residential area which is located next to the city centre, directly behind the former city wall (see Figure 1) (Hiob et al. 2012). The common (or stereotypical) understanding of the neighbourhood used to be (and still continues to be) that Supilinn is one of the unique historic neighbourhoods with wooden houses, large plots with orchards and vegetable gardens and bohemian atmosphere. However, this image has already transformed due to fast gentrification processes since late 1990s. Currently, Supilinn has become a desired residential place with one of the highest property prices in town with new architecture (in larger volumes), denser plot structure and parking lots that have replaced the greenery (Nutt 2019). Supilinn territory is currently 0.48 square kilometres (Tartu city area is $\left.39 \mathrm{~km}^{2}\right)$.

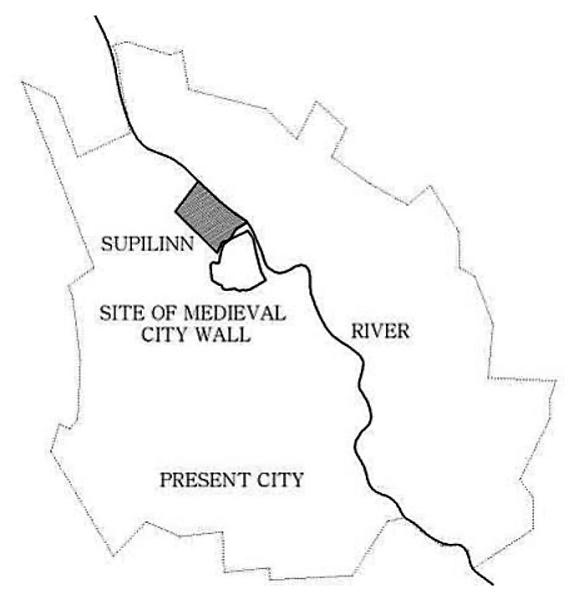

Figure 1 . Supilinn, currently one of the 17 th city districts, is located next to the city centre, directly behind the former medieval city wall. City borders are shown with grey line. 
Historically, most of the district has been part of the city since the 17th century (Hiob 2012). In the mid-18th century landowners of the district were mostly city government members, wealthy citizens, clerics or nobles (Teedema 2010). After the collapse of the Soviet Union and the restoration of Estonian independence in 1991, radical changes started to form the society, and thus the image of the district Supilinn as a run-down slum began to change. The region was first occupied by artistic people and bohemians (i.e. first wave gentrifiers) who squatted in the abandoned houses. Their sense of freedom and free spirit attracted people who were not naturally bohemian. The bohemians left the neighbourhood as new people purchased land and properties and started changing the area. The sense of freedom was replaced by fences around private properties, which were installed there by the new owners. Although the people were attracted to the bohemian lifestyle and organic living environment, they began to restore and create order.

Amongst this new population (i.e. second wave gentrifiers) it became popular to fix up and renew the area as well as organize the district festival (Liin 2012) to provide entertainment and achieve some recognition (reputation). The district also provided opportunities for residents to display their wealth and 'show off'. The people that were then attracted to the excitement of the new city district brought with them more assets. These new values were quickly materialized in the area in the form of asphalt roads and freshly painted fences. Property prices soared (Nutt 2014) and a solvent population (i.e. third wave gentrifiers) was formed from people who believed in these 'middle-class values'. Their dream of a beautiful home included a driveway. The municipality gave out building permits to property businessmen (Nutt 2014, 2019) who tried to make maximum profit out of (initial) low prices per square metre. This in turn threatened the second wave gentrifiers' vision of this urban

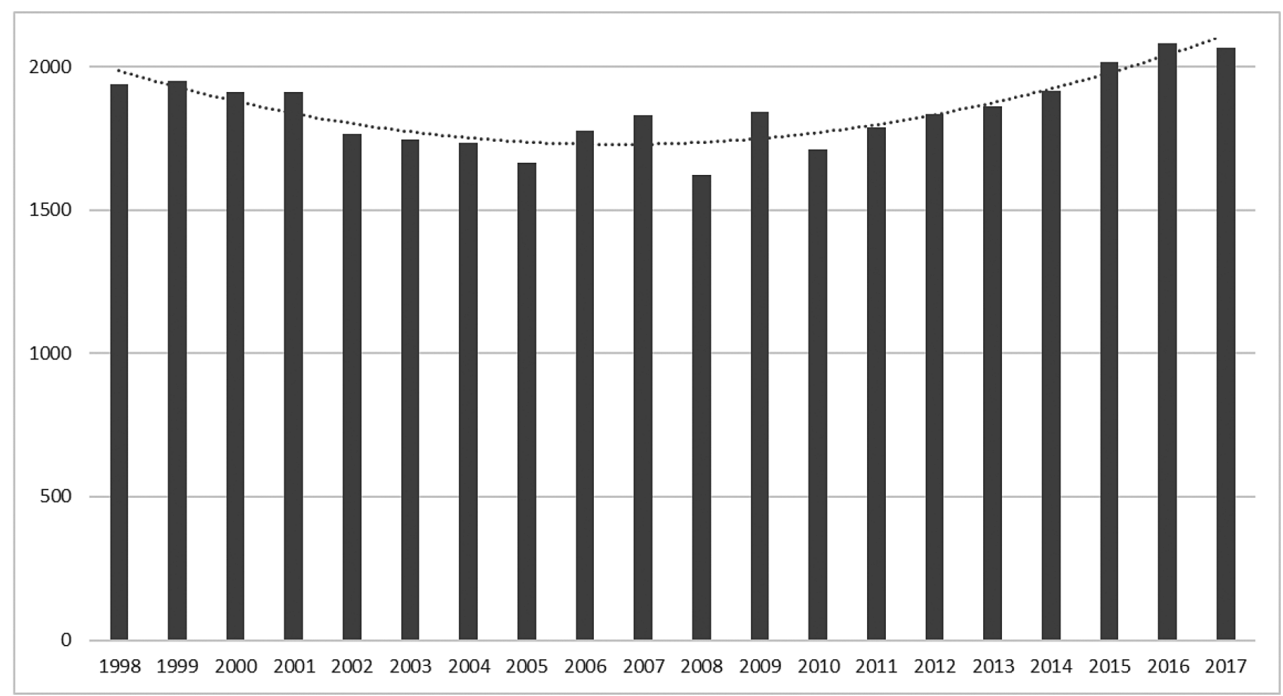

Figure 2. Change in population in Supilinn district in 1998-2017. In 2019, there were 2073 inhabitants in Supilinn. Source: Tartu City Government 2021. 
district, so they tried to stop the development at all cost, meanwhile creating their own version of Supilinn, which was completely different from the actual identity of the district. As described by a local resident, ,, What has also changed over the years is that when I moved here all of the general communication was somehow freer, like the attempt to preserve privacy has increased. Maybe it is no longer as open as it was when I moved here. "(Supilinna Selts 2011) or by another community member, "It still picks up the people who think the same way. The contingent of new houses... really do not know that somebody from the new houses would have blended in, these new houses are still rather separate 'islands.," (Supilinna Selts 2011). The change in neighbourhood's population is illustrated in Figure 2.

Hence, the district can be considered a gentrifying area neighbouring the city centre (Hiob et al. 2012, Nutt 2012, Nutt et al. 2013). As is characteristic of gentrification, the property prices rise, the demographics of the residents change and the popularity of the region increases. The results of the previously conducted studies (Hiob and Nutt 2010) confirm that new people who relocated to the area have thereby changed the region. People today live different lives than previous residents and spend more time behind closed doors. They seem to wish more privacy. The physical conditions of the built environment are reflective of the change in the mentality of residents. Although the quality of built environment has improved - the roads have been repaired and the majority of houses have been refurbished, the district is no longer perceived as being free and open (see Figure 3).
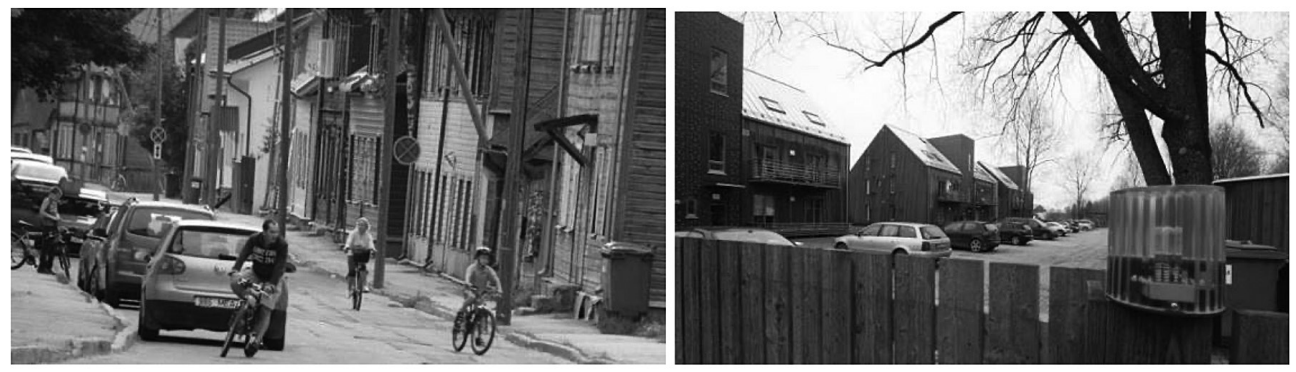

Figure 3. Changes occurring in the gentrifying area are visible in the cityscape.

On the left: active use of public space. On the right: enclosed private courtyard of a new residential building used as a parking lot. No passage, the gate opens by remote control only.

Source: Nutt 2012. 


\section{Results \\ 5.1. The impact of gentrification on the construction of social representation in Supilinn}

The research findings indicate that the construction of Supilinn's phenomenon of social representation is closely related to the gentrification process. Particularly, the second wave gentrifiers exploit the image of the first wave 'pioneers' and construct a more suitable phenomenon for them. This type of phenomenon construction can be seen in the case study area. The basis for constructing the phenomenon of social representation began more than two decades ago, when the bohemian sense of freedom and state of mind created a favourable environment. The second wave of gentrification occurred due to the subsequent community members who moved to the neighbourhood. They skilfully used the favourable environment to construct a unique representation of the neighbourhood and community. As such, they created an image of Supilinn as a strong and unified community that values the principles of civil society. The district is known to be a friendly, compact, green neighbourhood, which stands up for itself, has close relationships within itself, is a role model for other districts, carries the ideas of civil society, and is loved by the community members. The most active people of the community gathered in the local neighbourhood association, a non-profit organization founded in 2002 (Liin 2012). Due to the horizontal structure of the organisation, Supilinn association has had favourable grounds for social trust and cooperation to emerge from the outset (see Figure 4). Community engagement is one of the major characteristics of the Supilinn association that operates on the basis of voluntary work. The association has an elected board, which facilitates and organises the communication between the state/ local government and the organisation. The main aim of the board is to coordinate and disseminate information (vs giving orders and determining assignments). No
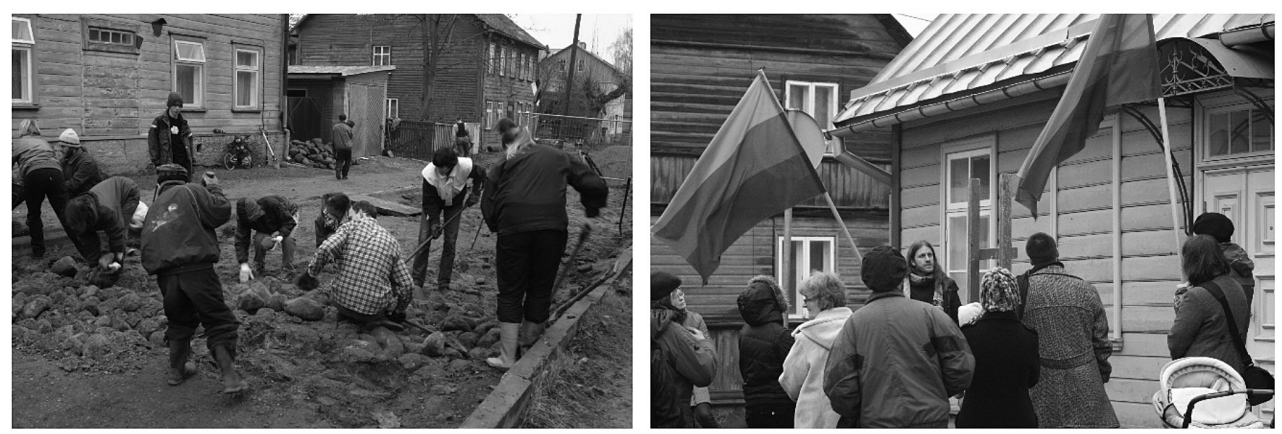

Figure 4. Events of Supilinn association that create social trust and engage the community. On the left: Organized campaign to preserve the cobbled street (a public statement about paving all streets with asphalt). On the right: Procession with flags of Supilinn in recognition of its most beautiful houses in 2012. Sources: Haamer 2003, Nutt 2012. 
events or initiatives would take place without community engagement (see Figure 5). For instance, if someone proposes to plant trees, the same person should be willing to take the lead. The board will support the initiative and helps to find investors and coordinates cooperation with local government (incl applying of required permits) if necessary.
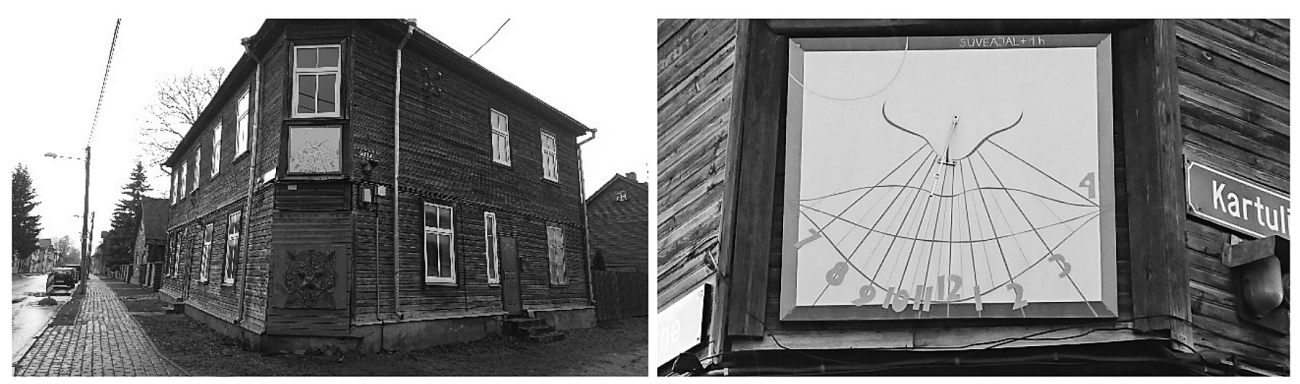

Figure 5. Example of the activities of the association with horizontal structure.

The sundial has been mounted on the wall of the house in Supilinn by the initiative of local residents, and another resident initiated the display of knitted cat picture on the wall (lower).

The board of the association helped to finance the instalment of the the sundial and settle the agreement with the owner of the house for the cat-picture. These projects were carried out by the residents with ideas, the board only provided support. Source: Nutt 2020.

Under the leadership of an active group from the organization, an annual spring festival Supilinn Days is held, which has continued to expand every year. Organizing this major event has, among other things, contributed to a strong online presence of Supilinn association in the form of homepage, mailing lists and Facebook. This neighbourhood festival has become a well-known traditional open-air event in the city. In addition, Supilinn association has been actively involved in the spatial planning process of the area through constant communication with the media and municipality. The active involvement of locals creates direct contacts between people, which builds interpersonal trust, and helps the organization as the voice of the community to achieve its goals. The fact that the organization is highly trusted is indicated in a survey conducted among the local residents. $88 \%$ of the respondents are familiar with the organization's activities and a majority of them (84\%) have the opinion that the activities of association have had a positive impact on Supilinn. In addition, people believe that in further activities the association should be as active as it has been ( $54 \%$ of the respondents) or even more active (44\%). Therefore, the organization has a role as an opinion leader, which in turn has secured the residents' quick acceptance of the construction initiated by the organization. Without going into detail, the same developments are happening in other gentrifying regions in post-Soviet Estonia in general, which are also quickly gaining popularity and where the construction of the phenomenon is conscious and purposeful. 


\subsection{The constructed phenomenon of social representation being used as social capital}

\subsubsection{Belonging to a community - Supilinn neighbourhood association}

A social group called Supilinna Selts (in Estonian, referring to Supilinn neighbourhood association) was established over a decade ago and it brings together people who appreciate the values of the district. The association has become significant in the social world as a carrier of social representation, and Supilinn with its unique identity serves as an object in this construction. The interviews carried out with key individuals reveal that the residents of Supilinn prefer the old and unique environment - as the area used to be. The interviews also point out that residents of Supilinn in general are not bothered by the fact that their community was considered to be a run-down slum where investment was not considered to be rational in the previous eras. The average resident of Supilinn can also be described as a rather natural, not too proper, free spirited person. Perhaps even as a person who is considered to prefer soft values to material wealth. However, the interviews emphasized that it would be wrong to consider all Supilinn inhabitants to be one mass with identical values. Similarly to the houses and streets of the area, diversity prevails among the residents. Diversity is also highlighted as a particular value of the district. Also, it was pointed out as a characteristic to the district's social interaction that, as if in a village community, residents of Supilinn know each other - the neighbours are known as well as the village drunks. As illustrated by respondents,

I do think that people of Supilinn are a little bit different. There is still a sense of identity and a sense of the district - it is considered as our own territory. And our own territory is not confined to the house or the apartment, but the entire district is much more deeply ,our own” than Tartu as a whole. /.../It is somehow like an extended feeling of a homethat you know these houses, these gardens; you will notice if something has changed - whether it be for the better or for the worse. You know how, you can pay attention to it (Supilinna Selts 2011).

Resulting from the structured surveys conducted among Supilinn residents, it is evident that there is almost a complete consensus among the respondents that Supilinn is a pleasant and valuable living environment. Ninety-nine per cent of the respondents admit that they like to live in the district. Not a single person responded that they did not like Supilinn. Thus, the attitude of all the respondents was positive towards their environment, and decisive factors that would make the area unattractive did not exist for them. Ninety-five per cent of the respondents themselves identified with the Supilinn community, while only $4 \%$ did not. It is noteworthy that the latter group (4\%) have only lived in Supilinn for an average of 3.6 years. Their limited time in the community could explain why the respondents did not consider themselves as members of the community (yet) (see Figure 6). 

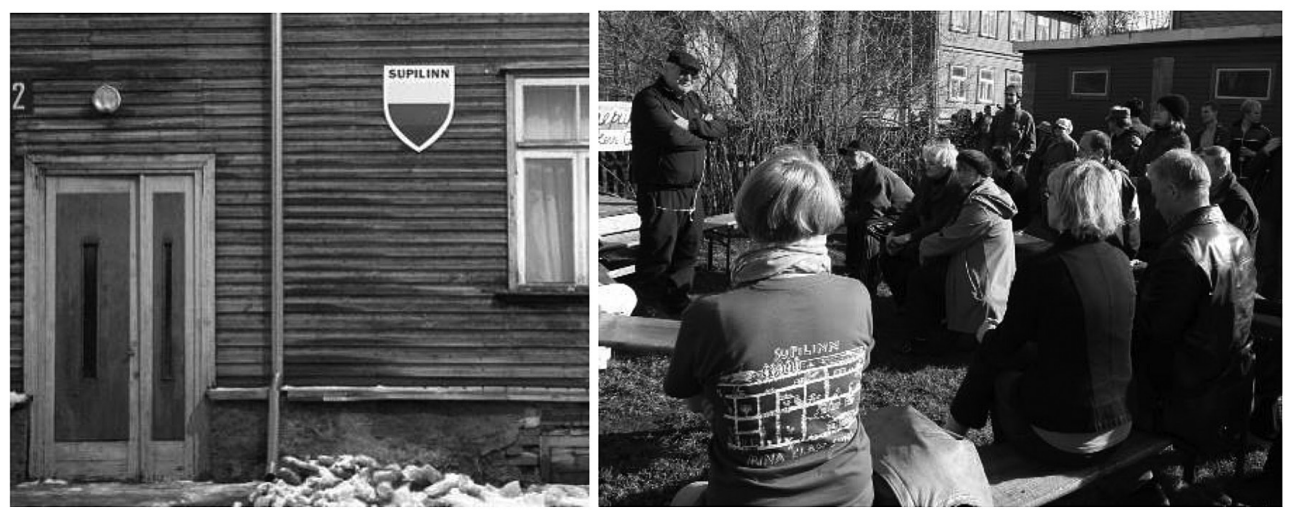

Figure 6. Local identity is very strong, almost all residents self-identified with the Supilinn community. They label not only the district border but also themselves. On the left: the mark of Supilinn district border - coat of arms on the wall of a house. On the right: Supilinn Festival T-shirt with a layout of district map in the foreground of the photo. Source: Nutt 2018, 2010.

In the last decade the neighbourhood association and its annual festival have played a significant role. The association's role in creating the sense of community was considered important by $62 \%$ and as of average importance by $27 \%$ of the respondents. Thus, $89 \%$ assessed the organization's role to be positive in creating a sense of community. Consequently, belonging to a community as part of constructing social capital is well manifested in Supilinn's gentrification process.

\subsubsection{Knowing the neighbourhood}

A community's strength and social capital is also characterized by whether or not residents know their fellow citizens. Acquaintances in the neighbourhood show, on the one hand, if the district is perceived as a whole and, on the other hand, if people are familiar with all the streets. Research findings showed that fellow inhabitants of Supilinn were known by $92 \%$ of the respondents. A majority of respondents claim they are acquainted with a lot of people in Supilinn whereas $6 \%$ claim to know people only on their street, and 9\% know people only from their house.

In Supilinn, the most common type of building is a small apartment building. Although there are also plenty of private houses, $97 \%$ of respondents consider interaction with neighbours to be affirmatively important (Hiob and Nutt 2010). According to respondents, the district's residents interact with each other for at least a few times a week $(33 \%)$, a few times a month $(25 \%)$, and a few times in a quarter $(12 \%)$, whereas some did not interact at all (17\%). Also, the destination-based identity was very strong as $96 \%$ of the respondents identified with Supilinn. Out of all the respondents, $85 \%$ agreed that there was a strong sense of community, $96 \%$ agreed that Supilinn was a tranquil living environment, and $95 \%$ agreed with the statement that the living environment was free and easy. The atmosphere was also considered to be special, Supilinn-like, by $96 \%$ of the respondents. The preservation 

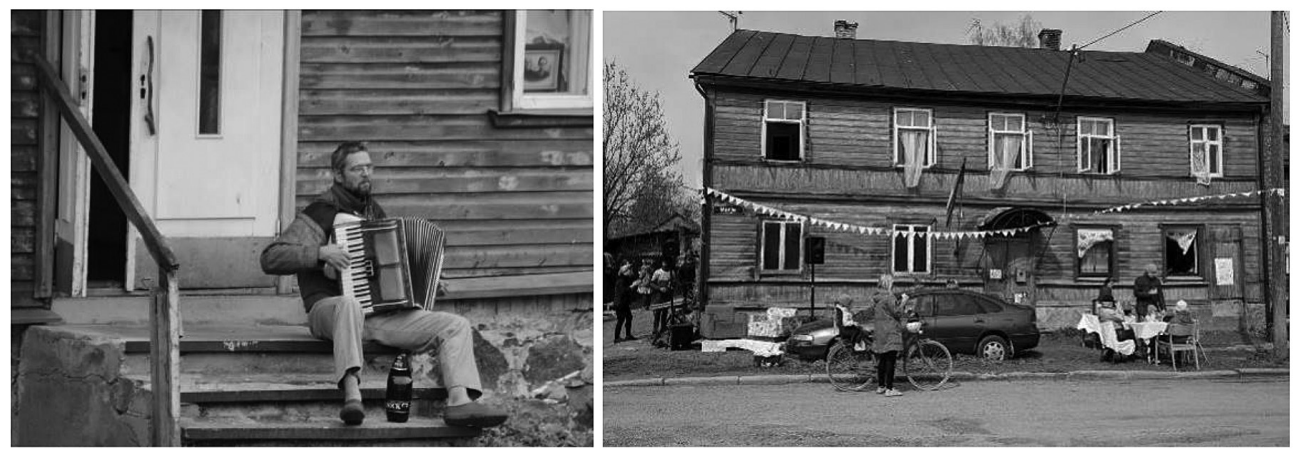

Figure 7. Knowing the neighbourhood and spotting the diversity. On the left: a local musician.

On the right: people in a pop-up street cafeteria. Source: Nutt 2015, 2018.

of Supilinn's peculiarity was important to $99 \%$ of the respondents (Supilinna Selts 2011). For a majority of the residents the boundary of their home is not their apartment walls, their house door, nor their garden gate or even their home street, but according to the results from the surveys their home (perception of home) spreads to the border of Supilinn.

In addition, the sense of identifying with Supilinn was very strong among the district's residents, in spite of which gentrification wave they belonged to. One of Supilinn's social values is social diversity due to its small size, compactness, and lifestyle, which has manifested itself in the plurality of education, economic welfare, age, and lifestyle to name a few (see Figure 7). Consequently, the region is socially very rich and diverse. According to Putnam's theory there could be networks occurring at many levels, which have influenced the region positively as it has accumulated social capital.

\subsubsection{The role of the neighbourhood's association}

In Supilinn's case the most visible group is related to the Supilinn association, which contains smaller groups or committees comprised of active members of the organization. The organization, which enjoys great support of its residents, actively intervenes in the spatial planning issues of the community by having a continuous discussion with the authorities and by loudly and consistently fighting for their beliefs and values. The image or brand of Supilinn sells well and the press gladly prints about its events.

Furthermore, the association has developed and created unique symbols and initiatives that are part of its identity. For instance, the organisation started to publish an annual neighbourhood newspaper Supilinna Tirin (tureen or alternatively, the sound of a doorbell, in Estonian) and organise events for cleaning up the neighbourhood. Volunteers started to organise a district's festival Supilinn Days, which has become the major (even iconic) event. It should be noted that Supilinn festival was the first neighbourhood out-door festival in the whole town and it has been a role 
model for other similar festivals. Also, the district's regalia was developed: flag, coat of arms, and logo (see Figure 8). The social capital accumulated in Supilinn has a positive image and has become a so-called trademark, which also influences social situations - people are friendlier towards you once they realise you are from Supilinn.

The constructed phenomenon of social representation in Supilinn starts to work as social capital that is passed over to other residents of Supilinn, who simultaneously begin to identify with the community. In other words, a sort of an invisible web system forms between the community of Supilinn and its residents. Although intangible, it is perceivable, existent and appreciable to everyone involved. By defining themselves as residents of Supilinn other people's approval is ensured even more broadly. The positive part of Supilinn's image has the value of a currency in both politics and in cultural circles once it is established in the circle.

Active members of the voluntary work-based organization have influential positions in their everyday life as well and the established connections help outside of the collective activities. Therefore, the benefits of social capital are two-sided: personal and public. Strong social networks help a person to make a career if they know how to take advantage of the circle of acquaintances to which they are connected. The social control in the neighbourhood works in a similar way. Since everyone knows everyone else, there is less crime, a reliable chimney sweep can easily be found or getting a free refrigerator from your neighbour is usual.

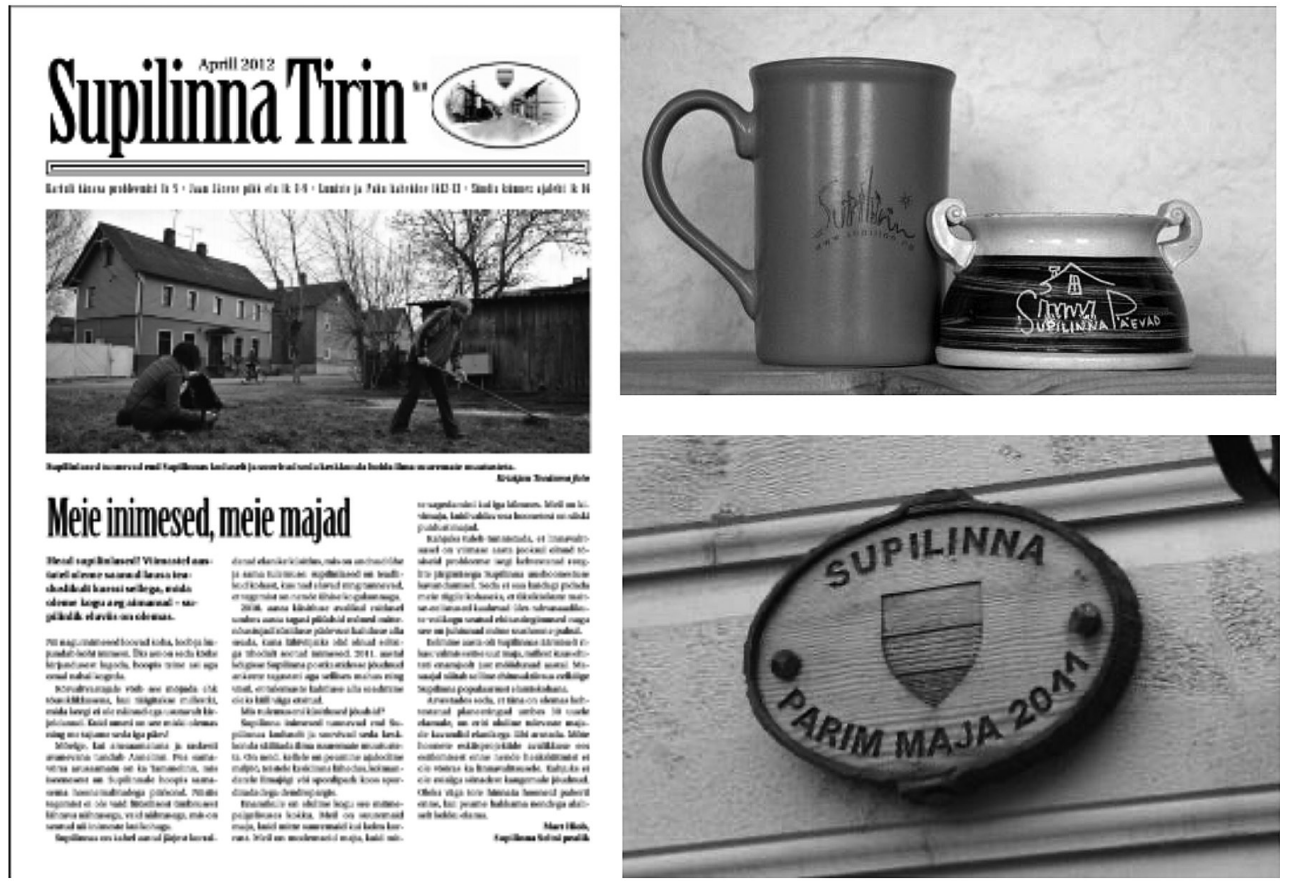

Figure 8. The insignia of the local neighbourhood association. Local newspaper Supilinna Tirin, Supilinn's mugs, and the label of the best house of the year (i.e. the prettiest). 


\section{Conclusion}

Two decades ago Estonia experienced major social-economic and political changes that resulted in a shift in people's thinking and way of life, which led to the change of urban structures and image of the places. The sense and perception of place increases over the years when a person lives within a community. Also, organizations that are based on voluntary work play an important role in encouraging communication between the residents and in development of trust. Self-identifying with the place and place attachment influences the person's behaviour as well as the neighbourhood as a whole.

With its horizontal networks and associated norms and values, the civil society has made a far-reaching social impact, which was identified in Supilinn case as well. Positive consequences for the people living in the community and the association at large have been made through the creation of individual and collective benefits. The leadership of the local organization, which promoted resident involvement and direct contact between local residents has created interpersonal trust. Close contacts between the residents, trust, and the acceptance of the established social norms have helped the community, including the organization, to achieve its goals. Local association has played an important role in the construction of the Supilinn's phenomenon of social representation and social capital. The members of the association, as well as the residents of the neighbourhood are united by a shared ideology and values.

In Supilinn's case it is an occurrence of social representation, which connects people and is constantly covered in the media. It has become a metaphor through stories, pictures, and tales. The major finding demonstrates that although the development and creation of the phenomenon started earlier in Supilinn, the major constructors of social representation and social capital are the people of the second wave of gentrification who have concentrated their involvement in the local association, which leads the way.

In conclusion, the characteristics of constructing the phenomenon of social representation and social capital, according to social representation theory, manifested in the Supilinn district are as follows:

1. There was a suitable object (grounds) for constructing the phenomenon a unique and once unpopular district;

2. A group of residents with creative image and free spirit (i.e. bohemians, first wave gentrifiers) moved to the abandoned area and created prerequisites for constructing the phenomenon;

3. Following residents of the region (i.e. second wave gentrifiers) skilfully used the possibilities of the attractive and re-born neighbourhood to construct a unique phenomenon; this study highlights that the construction of Supilinn's social representation is particularly related and guided by the second wave gentrifiers. 
4. The identity of community members is largely based on the constructed phenomenon of social representation, which is eventually being used as social capital that has various benefits (i.e., personal and communal).

5. There are close mutual relations between social representation and social capital theory and the process of gentrification. Gentrification sets the stage for constructing the image (i.e. imago or representation) that results in social capital. However, in turn, social representation and creation of social capital guides the gentrification dynamics as well.

6. An interesting contradiction can be noted in the case study area. Although the social capital accumulated and currently used in Supilinn has a positive image (it has become a so-called trademark), various conflicts of values among residents (by different waves of gentrifiers) have been evident at the same time. Consequently, the constructed roots of social capital may be erased or completely transformed in gentrification process as it contributed to the production of this phenomenon in the first place.

There are several communities in Estonia that have gone through similar processes in terms of gentrification. In order to see if and how, and to what extent the social representation and social capital have manifested in these neighbourhoods, further studies should be carried out. Also, to evaluate if and how the social phenomena explored in current paper would transform over time with new residents and their perceptions of place, a new repetitive study should be conducted. Only time will tell whether we see a completely different attachment to place and characteristics of Supilinn identity and a transformed social capital.

Addresses:

Nele Nutt (corresponding author), Zenia Kotval, Kadri Mets, Sirle Salmistu

Tartu College

School of Engineering

Tallinn University of Technology

Puiestee 78, 51008 Tartu, Estonia

Email: nele.nutt@taltech.ee

Zenia Kotval

Professor and Program Director of Urban and Regional Planning

School of Planning Design and Construction

552 W. Circle Drive

Michigan State University, USA

Email: kotval@msu.edu 


\section{References}

Ait, J. (2015) Juhkentali asumiseltsi kujunemisest: ideedest tegevusteni. [The formation of Juhkental civil society organisation: from the idea to action.] Unpublished master's theses. Tallinn: Tallinn University.

Amsden, B. L., R. C. Stedman, and L. E. Kruger (2011) "The creation and maintenance of sense of place in a tourism-dependent community". Leisure Sciences 33, 1, 32-51.

Anderson, A., J. Platt, I. Skelton, G. Butler, P. Chorney, E. Funk, and B. Grant (2005) "Social investment in the inner city: community and capital in West Broadway, Winnipeg". Canadian Journal of Urban Research 14, 1, 8-31.

Arefi, M. (1999) "Non-place and placelessness as narrative of loss: rethinking the notion of place". Journal of Urban Design 4, 2, 179-193.

Atkinson, R. (2000) "The hidden costs of gentrification: displacement in Central London". Journal of Housing and Built Environment 15, 4, 307-326.

Atkinson, R. (2004) "The evidence on the impact of gentrification: new lessons for the urban renaissance?". European Journal of Housing Policy 4, 1, 107-131.

Bauer, M. W. and G. Gaskell (1999) Towards a paradigm for research on social representations. Journal for the Theory of Social Behavior 29, 163-185.

Bourdieu, P. (1977) Outline of a theory of practice. Cambridge: Cambridge University Press.

Brouillette, S. (2009) "Literature and gentrification on Brick Lane". Criticism 51, 3, 425-449.

Brown, B. B., D. Perkins, and G. Brown (2003) "Place attachment in a revitalizing neighborhood: individual and block levels of analysis". Journal of Environmental Psychology 23, 3, 259-271.

Coleman, J. (1990) Foundations of social theory. Cambridge, Massachusetts, and London, England: The Belknap Press of Harvard University Press.

Corcoran, M. (2002) "Place attachment and community sentiment in marginalised neighbourhoods: a European case study". Canadian Journal of Urban Research 11, 1, 47-67.

Crawford, P., Z. Kotval, W. Rauhe, and Z. Kotval (2008) "Social capital development in participatory community planning and design". Town Planning Review 79, 5, 533-553.

Friedmann, J. (2010) "Place and place-making in cities: a global perspective". Planning Theory \& Practice 11, 2, 149-165.

Grifith, J. M. (1996) "Gentrification: perspectives on the return to the central city". Journal of Planning Literature 11, 2, 241-255.

Hanifan, L. (1920) The community center. Boston: Silver, Burdett.

Haworth, L. (1958) "Reviewed work(s): a natural science of society by A. R. Radcliffe-Brown". Philosophy of Science 25, 4, 299-300.

Hiob, M. (2012) "Planeeringuline kujunemine. Supilinn 17.-21. sajandi linnakaartidel ja -plaanidel". [Development of Supilinn's street and plot structure - Supilinn on maps and plans between the 17th and 21st century.] Acta Architecturae Naturalis 2, 50-76.

Hiob, M. and N. Nutt (2010) Supilinna teemaplaneeringu muinsuskaitse eritingimused. [Conditions of cultural heritage protection in thematic plan of Supilinn.] Tartu, Estonia: Artes Terrae.

Hiob, M. and N. Nutt (2016) "Spatial planning in Estonia: from a Socialist to inclusive perspective". Transylvanian Review of Administrative Sciences 47 E, 63-79.

Hiob, M., N. Nutt, S. Nurme, and F. De Luca (2012) "Risen from the dead: from slumming to gentrification". Transylvanian Review of Administrative Sciences 36 E, 92-105. 
Käärik, H. (2013) Pierre Bourdieu, klassikaline ja nü̈̈disaegne sotsioloogiline teooria. [Pierre Bourdieu, classical and contemporary sociological theory.] Tartu: Tartu Ülikooli kirjastus.

Kubeš, J., and Z. Kovács (2020) "The kaleidoscope of gentrification in post-socialist cities". Urban Studies 57, 13, 2591-2611.

Liin, A. (2012) "Supilinna Selts: kujunemine ja roll”. [Supilinn Society: its formation and role.] Acta Architecturae Naturalis 2, 111-129.

Manzo, L. C. (2003) "Relationships to non-residential places: towards a reconceptualization of attachment to place". Journal of Environmental Psychology 23, 1, 47-61.

Moscovici, S. (1984) The phenomenon of social representations. In R. M. Farr and S. Moscovici, eds. Social representations, 3-69, Cambridge: Cambridge University Press.

Narayan, D. and M. F. Cassidy, (2001) "A dimensional approach to measuring social capital: development and validation of a social capital inventory". Current Sociology 49, 2, 59-102.

Norris, P. and R. Inglehart (2004) "Religious organizations and social capital". In their Sacred and secular: religion and politics worldwide, 180-195. Cambridge: Cambridge University Press.

Nutt, N. (2003) "Supilinn - Eesti stiilipuhtaim agul”. [Supilinn - the most stylish slum in Estonia.] Unpublished final's theses. Tallinn, Estonia: Estonian Academy of Arts.

Nutt, N. (2012) “'MINA ELAN SIIN' - elavustumine Supilinnas" ['I live here' - the livening of Supilinn.] Acta Architecturae Naturalis 2, 93-110.

Nutt, N. (2017) Ühiskondlike normide muutumine ja omaksvõtmine gentrifikatsiooniprotsessi käigus Tartu Supilinna kogukonna näitel. [The change and acceptance of social norms in gentrification processes by the example of Supilinn Community in Tartu.] Master Theses. Tartu, Estonia: University of Tartu.

Nutt, N. (2019) "Challenge of urban regeneration in Post-Socialist city: Supilinn gentification recovered district". Acta Architecturae Naturalis 5, 70-83.

Nutt, N., M. Hiob, and Z. Kotval (2016) "Supilinn, Tartu - the lively vernacular against urban renewal: a Lefebvrean critique". Space and Culture 2, 1-13.

Nutt, N., M. Hiob, and S. Nurme (2012) "The story of 'ugly duckling': the run-down slum that survived the socialist system of government has turned to desirable residential area". In 15th International Planning History Society (IPHS) Conference, São Paulo, Brasil, 15-18 July, 2012.

Nutt, N., M. Hiob, S. Nurme, and S. Salmistu (2013) "Gentrification in a Post-Socialist town: the case of the Supilinn District, Tartu, Estonia". Transylvanian Review of Administrative Sciences, Special Issue, 109-123.

Proshansky, H. M. (1978) “The city and self-identity”. Environment and Behavior 10, 2, 147-169.

Proshansky, H. M., A. Fabian, and R. Kaminoff (1983) "Place-identity: physical world socialization of the self". Journal of Environmental Psychology 3, 1, 57-83.

Putnam, R. (2000) Bowling alone: the collapse and revival of American community. New York: Simon \& Schuster.

Rämmer, A. (1998) "Kuidas ühiskondlikud muutused mõjutavad sotsiaalseid representatsioone: ettekujutused ühiskonna kihistumisest". [How social changes affect social representations: Estonians' representations of social structure.] Akadeemia (Tartu) 10, 2099-2125.

Supilinna Selts (2011) Osalusplaneerimine Supilinna teemaplaneeringu koostamisel. [Participatory planning during compiling the thematic plan on Supilinn.] Available online at $<$ http://www. supilinn.ee/files/Supilinna_intervjuude_aruanne_veebi.pdf > . Accessed on $22 \operatorname{March} 2021$. 
Sztompka, P. (1996) “Trust and emerging democracy: lessons from Poland”. International Sociology $11,1,37-62$.

Tartu City Government (2021) Rahvastik. Interaktiivne statistikarubriik. Tartu statistilised näitajad. [Population. Interactive statistics. Tartu in figures.] Available online at $<$ https://www.tartu.ee/ et/statistika>. Accessed on 5 February 2021.

Taylor, R. B. (1996) "Neighborhood responses to disorder and local attachments: the systemic model of attachment, social disorganization, and neighborhood use value". Sociological Forum 11, 1, 41-74.

Teedema, L. (2010) Supilinna asustuse kujunemine 1704-1899. [The development of the settlement in Supilinn from 1704 to 1899.] Unpublished master's theses. Tartu, Estonia: University of Tartu.

Wagner, W. (1998) "Social representations and beyond: brute facts, symbolic coping and domesticated worlds". Culture \& Psychology 4, 3, 297-329. 